\title{
EMIGRATION AND REMITTANCES PATTERN ANALYSIS IN LAGGING-BEHIND REGIONS OF THE BALTICS: CASE STUDIES FOR NARVA, DAUGAVPILS AND VISAGINAS
}

\author{
Emigrācijas un transfērmaksājumu izpēte Baltijas valstu \\ nomales reǵionos: Narvas (Igaunija), Daugavpils (Latvija) un \\ Visaginas (Lietuva) piemēru analīze
}

\author{
Mihails Kozlovs \\ University of Latvia, Faculty of Geography and Earth Sciences \\ mihails.kozlovs@gmail.com
}

\begin{abstract}
In this paper the author is studying the economic effect of emigration in three lagging-behind Baltic regions over the past decade. During this time span the influence of emigration on the economy is analyzed in terms of the size of migration flows, taxation system differences and the level of remittances in the Baltic countries, all of which affect local economies / communities.

An analysis in made of three distinctive lagging-behind regions: Estonian Narva, Latvian Daugavpils and Lithuanian Visaginas. The overall impact of emigration on the economies of the Baltic countries is evaluated by a weighting of negative and positive factors.

In order to measure the influence of emigration on the selected Baltic economies - two quantitative approaches were developed. Each of these scenarios contains different sets of parameters and these combinations describe the economic impact of migration. Underlying formulae of the undertaken approaches, with small modifications, may be used for the examination of similar issues in other regions and countries.
\end{abstract}

Keywords: economic migration, remittances, taxes, Baltic region, lagging-behind regions, Narva, Daugavpils, Visaginas

\section{Introduction}

Migration nowadays is a new norm for the expression of attitude. People are leaving one socio-economic environment in order to explore the benefits of another. Migration derives from a set of fundamental causes: inequalities in development, employment prospects, incomes and living conditions between and within the countries (King 2008).

The World Bank's annual research on migration shows that the quantity of people changing location is constantly growing (WB 2017). The size of remittances and money transfer services are following the same trend and developing rapidly.

Latvian emigration studies undertaken by O. Krasnopjorov (2011) and M. Hazans (2013) prove that emigration from Latvia has had a significant impact on the economy. M. Hazans reported that emigration could be up to 200 thousand people, which is more than $10 \%$ of the Latvian population. Migration researcher O. Krasnopjorov analyzed emigration patterns by comparing in-flows and out-flows of people at Riga airport and at Latvian harbours. He concluded that the total number of emigrants could be around 177 thousand people.

Not only Latvia, but the whole Baltic region was hugely influenced by emigration over the last ten years. Latvians, Lithuanians and Estonians were leaving in 
massive numbers towards the direction of the Western and Northern European countries. A number of studies show the negative impact of emigration (Krasnopjarov 2011) and fewer researches are taking a balanced approach in analysing not only the negative side of the emigration, but also the benefits (Hazans 2013).

In this study the author is modelling the economic impact of emigration not only on the national economies of each of the Baltic countries, but as well on the regions, which are exposed to emigration to the highest extent. Economically lagging-behind regions in the Baltics during the past ten years have been experiencing both the positive and negative impacts of migration.

It is essential to emphasize that in some cases it was impossible to extract statistical information about all three economically lagging-behind cities - Narva, Daugavpils and Visaginas. In these cases - information was gathered about the larger statistical regions - Ida-Viruma, Utena and Daugavpils counties.

Skilled and unskilled migrants have an opposite effect on the expenditure of government programs such as unemployment compensation and other existing social benefit (Borjas 1995). But it is important to mention that models in this research are examining the very basic relationship between migrants and their national economies and the skills and professional degrees of the emigrants are not taken into consideration in these basic scenario calculations.

The regional scope of this research is linked with the distinctive economically lagging-behind regions: Estonian Narva, Latvian Daugavpils and Lithuanian Visaginas. The objective of this study is (1) to measure the behaviour of emigration in the selected regions (2) to compare the emigration process and its patterns within the Baltic countries and (3) to evaluate the overall impact of emigration in economically lagging-behind regions.

\section{Data and Methods}

The main limitation for this study was the unavailability of regional statistics and the segmentation of national data into the regions. This study is based on statistical information analysis and on the adjustment of available data on laggingbehind regions.

While studying emigration and remittances in the economically lagging-behind regions the author of this study was using different international organisation sources World Bank annual reports (2017), The International Organisation for Migration and information from each of the three Baltic country statistics bureau data bases (2018).

As well, and in order to understand the impact of migration, the author developed an economic equation, where taxes, number of emmigrants, and remittance levels are encapsulated. In economic terms, emigration translates into unpaid taxes from salaries and from the everyday expenditure on goods and services (Borjas 1995). At the same time, the migrant country-of-origin economy is gaining remittances and expenditure tax, which is paid from spending the money received from emigrants. 
Two scenarios were developed with a different impact ratio to the emigrant countryof-origin economies.

In the first model, the smallest impact on emigrant country-of-origin economies is projected. In this scenario, factors such as average number of emmigrants per year, minimum wage level and Value Added Tax (VAT) are taken into consideration. VAT is multiplied with minimum wage in order to see the spending impact of one potential emigrant on the country-of-origin economy.

The second model is an average impact scenario on migrant country-of-origin economies. Average number of emmigrants per year, average wage, income tax and VAT are considered. It projects that all of the emigrants would have been paying taxes from an average salary and VAT from the expenditure had the emigrants stayed in the country-of-origin. So, in this model, the average wage is multiplied with VAT and Income tax in order to evaluate the impact of one potential emigrant on the country-oforigin economy.

In both models the author is comparing unpaid taxes with the size of existing remittances. In the first scenario the impact of one migrant is evaluated by VAT from a minimum wage expenditure. In the second scenario the impact of one migrant is evaluated by VAT and Income taxes from an average wage expenditure. In both scenarios the economic effect of emigrations is compared with existing remittances flow.

\section{Research Results and Discussion}

The three Baltic countries - Latvia, Lithuania and Estonia were facing the brutal reality of EU competition for labour over the past decade. Access to free movement throughout the EU in combination with economic problems in the Baltic region had a huge impact on the community. The population of the Baltic region in 2008 accounted for 6.7 million population. In less than a decade the Baltic region's population shrank by approximately 630 thousand people (Figure 1).

However, over the same time period all three Baltic economies gained a significant amount of remittances, which were sent by migrants to their families and friends back home. Since 2008, emigrants from the Baltic countries transferred more than 35 billion EUR to their homes and families (World Bank 2018).

The Baltic GDP has constantly been growing since 2010, but still in 2017 it did not reach pre-crisis level. Baltic remittances were following the track of the GDP fluctuations, but during the economic downturn remittances were more likely to grow, than fall. For example, in 2009 remittances slightly grew, while the economies of the three Baltic countries continued to shrink (Figure 1). 


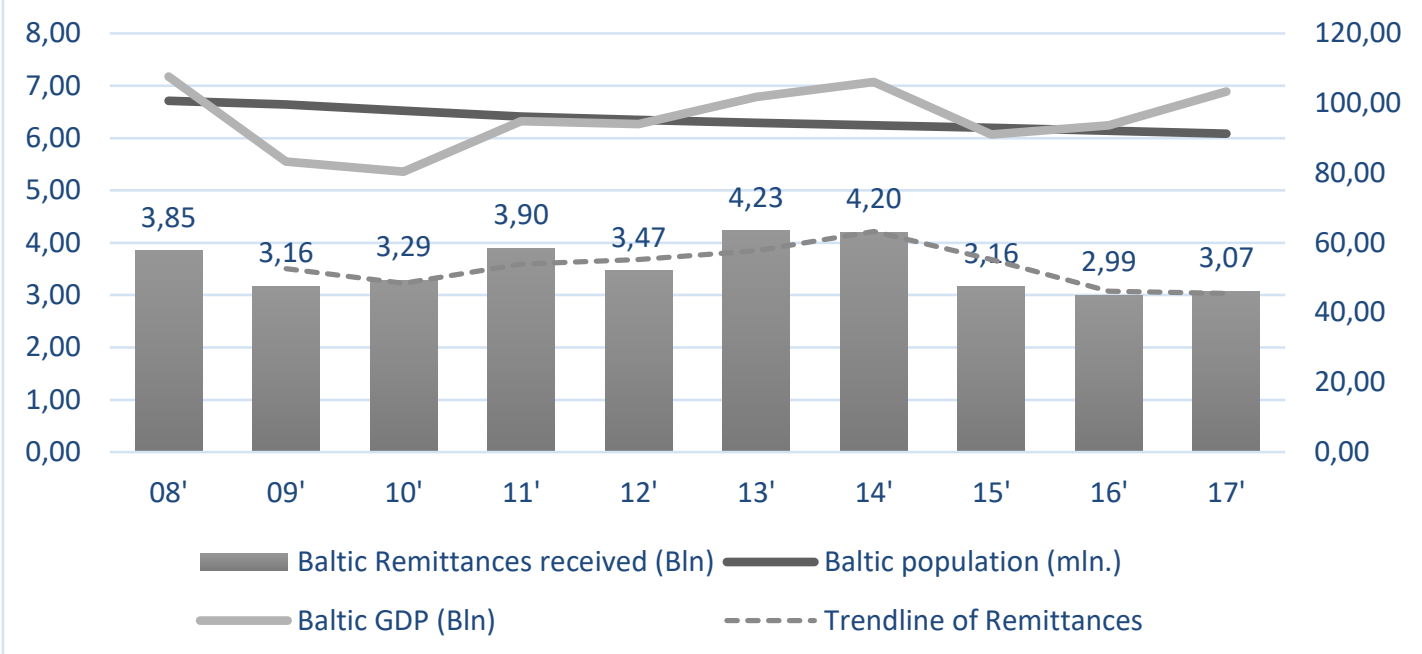

Figure 1. GDP, remittances and population change in Baltic region 2008-2017 (author's figure based on National Statistics Bureau data)

In less than ten years the Baltic countries lost a huge part of their population: Lithuania - more than 370 thousand, Latvia - 240 thousand and Estonia - 50 thousand people.

Remittances sent to Baltics were following the economic curves of the respective countries but only the Estonian market showed constant remittance growth throughout the past ten years. In Latvia the flow of remittances has been constantly falling since 2008. In Lithuania the growth of remittance amounts was rapid until 2015 and then remittances had a huge downturn by more than $35 \%$, however, the pace of de-population in Lithuania continued at the rate of 30 thousand people per year.

Another level of complexity is connected with regional disparities and levels of economic development within the Baltic countries. In an EU context, the Baltic region is not at all perceived as a lagging behind region. Nevertheless, several regions of Latvia, Lithuania and Estonia are economically lagging behind the average economic prospects in the Baltic region.

The Latvian Daugavpils, Estonian Narva and Lithuanian Visaginas regions all have many social, economic and even linguistic characteristics in common. All three towns are located in close proximity to the Eastern border of the EU, share a predominantly Russian socio-linguistic environment and all three regions are sharing a bad economic situation.

Baltic economically lagging regions can be divided into poor low-income and low-growth areas. For example, Estonian Narva and Latvian Daugavpils match with characteristics of a low-income area. These cities are converging rapidly and gaining higher value for the Estonian and Latvian economies. However, Lithuanian Visaginas is definitely a low-growth area, because it is experiencing stagnant productivity and job destruction. 
Table 1. Visual representation of GDP share in three lagging behind regions - Visaginas, Daugavpils and Narva (2008-2018) (author's calculations based on National Statistics Bureau data)

\begin{tabular}{|l|l|l|l|l|l|l|l|l|l|l|}
\hline $\begin{array}{c}\text { \% of the } \\
\text { GDP }\end{array}$ & $\mathbf{2 0 0 8}$ & $\mathbf{2 0 0 9}$ & $\mathbf{2 0 1 0}$ & $\mathbf{2 0 1 1}$ & $\mathbf{2 0 1 2}$ & $\mathbf{2 0 1 3}$ & $\mathbf{2 0 1 4}$ & $\mathbf{2 0 1 5}$ & $\mathbf{2 0 1 6}$ & $\mathbf{2 0 1 7}$ \\
\hline $\begin{array}{l}\text { Ida } \\
\text { Viruma } \\
\text { county }\end{array}$ & $8.0 \%$ & $7.60 \%$ & $8.20 \%$ & $8.30 \%$ & $7.60 \%$ & $7.90 \%$ & $7.30 \%$ & $6.50 \%$ & $6.00 \%$ & $6.00 \%$ \\
\hline $\begin{array}{l}\text { Daugavpils } \\
\text { county }\end{array}$ & $2.99 \%$ & $3.19 \%$ & $3.02 \%$ & $3.28 \%$ & $3.19 \%$ & $3.20 \%$ & $3.10 \%$ & $2.90 \%$ & $2.90 \%$ & $2.88 \%$ \\
\hline $\begin{array}{l}\text { Utena } \\
\text { county }\end{array}$ & $4.10 \%$ & $4.20 \%$ & $3.50 \%$ & $3.50 \%$ & $3.30 \%$ & $3.20 \%$ & $3.20 \%$ & $3.10 \%$ & $2.90 \%$ & $2.80 \%$ \\
\hline
\end{tabular}

Daugavpils is the second largest town in Latvia by population size, but it accounts only for less than $3 \%$ of GDP (Table 1). The capital of Rìga accounts for 54\% of GDP. The situation is similar in other Latvian cities with national status: Liepāja, Rēzekne, Jelgava, Jēkabpils, Jürmala, Valmiera and Ventspils. The total share of 8 Latvian national-status cities accounts for less than $15 \%$ of the Latvian GDP. And the weight of these towns is even downsizing: from 2013 to 2016 - the GDP share dropped by $0.9 \%$ (CSB 2018).

Narva city is the second largest town in Estonia in terms of population size. It is located in the Ida-Viruma region, which is facing similar regional development problems. Ida-Viruma's share in the Estonian GDP has been shrinking throughout the past decade and it is now around 6\% (Table 1). Similarly, as in the Latvian case - most of the Estonian economic activity is concentrated in the capital city, which accounts for more than 53\% of the Estonian GDP and, as well, Tallinn's share of the Estonian GDP is continuously growing (Statistics Estonia 2018).

In Lithuania the bulk of GDP is concentrated around several Lithuanian cities: Vilnius, Kaunas and Klaipeda. Economic activity in these three municipalities is generating more than $70 \%$ of the Lithuanian GDP. The four regions of Telšiai, Alytas, Marijampole and Utena account for approximately $15 \%$ of the national GDP. Economic activity is more widely distributed across Lithuania than it is in Latvia and Estonia.

However, these lagging behind regions have similar characteristics: The Utena county share of the National GDP decreased throughout last decade from $4.1 \%$ down to a $2.8 \%$ share of the GDP. But from the perspective of the population - Visaginas lost $35 \%$ of its population in the past 10 years (OSP 2018).

Throughout the past decade overall remittance levels in the Baltic countries decreased. In Latvia it dropped by $35 \%$, in Lithuania by $17 \%$. Estonia was the only country of the Baltic trio to see an uplift of remittances by over $39 \%$.

There is no official information about the distribution of remittance flows within each of the three Baltic countries. That is why the distribution of the remittances is adjusted to a regional share of the GDP. In such a way, remittances are distributed economically evenly. 
An adjusted distribution of the remittances in these regions followed and even deepened the trend, as on a national level: remittances in the Latvian Latgale region decreased by more than $38 \%$, in the Lithuanian Utena region by more than $43 \%$, but in the Estonian Ida-Viruma region grew by only 5\%. So, in the lagging behind regions distribution of the remittances is slowing down as well.

\section{Results}

The level of remittances is still relatively small in all three Baltic countries. As the five-year trend shows: the size of remittances has been decreasing continuously over the last five years. Nevertheless, the relative size of the remittances in 2017 in the Baltics is around 3\% (Figure 1).

In the first model it is projected that if all the emigrants stayed in Latvia they would have spent only the minimum wage and paid VAT to the national budget. This scenario reveals that, on average, each year one emigrant would have generated approximately 937 EUR paid as VAT. Alternatively, one emigrant, on average, in one year sends more than 2000 EUR as remittances.

The second model of the Latvian market shows that one emigrant, in economic terms for the Latvian budget, equals on average up to 4500 EUR in unpaid taxes annually. This model projects that each year, on average, the Latvian budget loses around 1 billion EUR from 220 thousand emigrants (Table 2).

Table 2. Model of emigration's average-impact scenario on the Latvian economy (author's calculations based on National Statistics Bureau data)

\begin{tabular}{|c|c|c|c|c|c|c|}
\hline & $\begin{array}{c}\text { Average } \\
\text { wage }\end{array}$ & VAT & $\begin{array}{c}\text { Income } \\
\text { tax }\end{array}$ & $\begin{array}{c}\text { Loss from 1 } \\
\text { migrant/monthly }\end{array}$ & $\begin{array}{c}\text { Loss from 1 } \\
\text { migrant/annually }\end{array}$ & $\begin{array}{c}\text { Loss from 220 } \\
\text { thousands of } \\
\text { migrants } \\
\text { annually (mln.) }\end{array}$ \\
\hline 2016 & 827 & $21 \%$ & $24 \%$ & 372.2 & $\mathbf{4 4 6 5 . 8}$ & 982.5 \\
\hline 2017 & 884 & $21 \%$ & $24 \%$ & 397.8 & $\mathbf{4 7 7 3 . 6}$ & 1050.2 \\
\hline 2018 & 961 & $21 \%$ & $24 \%$ & 432.5 & $\mathbf{5 1 8 9 . 4}$ & 1141.7 \\
\hline
\end{tabular}

Remittances sent from abroad are boosting the Latvian economy annually during the past decade the level of remittances never dropped under the 1.2 billion EUR benchmark. In terms of factors included in the second model, that means that emigration is still beneficial for the economy of the country-of-origin, but if the average wage continues to grow, then the benefit from taxes should outgrow the current benefit from remittances.

Similarly, if the Lithuanian economy was observed, through the prism of the first Model, then the value of one emigrant per year is on average 866 EUR. The overall effect from 350 thousand migrants annually has been growing for the last five years and in 2018 reached 353 million per year (Table 3). 
Table 3. Model of emigration's minimum-impact scenario on the Lithuanian economy (author's calculations based on National Statistics Bureau data)

\begin{tabular}{|c|c|c|c|c|c|}
\hline & $\begin{array}{c}\text { Minimum } \\
\text { wage }\end{array}$ & VAT & $\begin{array}{c}\text { Loss from 1 } \\
\text { migrant/monthly }\end{array}$ & $\begin{array}{c}\text { Loss from 1 } \\
\text { migrant/annually }\end{array}$ & $\begin{array}{c}\text { Loss from 350 } \\
\text { thousands of } \\
\text { migrants } \\
\text { annually (mln.) }\end{array}$ \\
\hline 2016 & 350 & $21 \%$ & 73.5 & $\mathbf{8 8 2 . 0}$ & 309 \\
\hline 2017 & 380 & $21 \%$ & 79.8 & $\mathbf{9 5 7 . 6}$ & 335 \\
\hline 2018 & 400 & $21 \%$ & 84.0 & $\mathbf{1 0 0 8 . 0}$ & 353 \\
\hline
\end{tabular}

On average, in the last 10 years, Lithuanian emigrants sent home a total amount of 1.606 billion EUR annually. In economic terms, every emigrant generates a 4.590 EUR value for the Lithuanian economy each year. This economic positive impact is 4 times higher than the annual loss of unpaid value added tax from the minimum wage.

In the last five years the level of remittances decreased, but it is still a substantial amount and remittance amounts are higher than possible unpaid VAT and income taxes from the average local salary. However, if the decrease of remittances continues, then almost certainly the total amount of unpaid taxes from 350 thousand emigrants will have a higher economic impact on the Lithuanian state budget.

In Estonia the size of the emigration flow was much smaller than in the other two Baltic countries. Overall, 50 thousand people emigrated and annually, on average, 451 million. EUR were sent as remittances. This means that every Estonian emigrant generated more than 9030 EUR annually for the Estonian state budget. This was twice as much as the Lithuanian emigrant and 1.5 times more than the Latvian emigrant.

Table 4. Model of emigration's average-impact scenario on the Estonian economy (author's calculations based on National Statistics Bureau data)

\begin{tabular}{|c|c|c|c|c|c|c|}
\hline & $\begin{array}{c}\text { Average } \\
\text { wage }\end{array}$ & VAT & $\begin{array}{c}\text { Income } \\
\text { Tax }\end{array}$ & $\begin{array}{c}\text { Loss from 1 } \\
\text { migrant/ } \\
\text { monthly }\end{array}$ & $\begin{array}{c}\text { Loss from 1 } \\
\text { migrant/ } \\
\text { annually }\end{array}$ & $\begin{array}{c}\text { Loss from 50 thousand } \\
\text { migrants annually } \\
\text { (mln.) }\end{array}$ \\
\hline 2016 & 1146 & $20 \%$ & $20 \%$ & 458.40 & $\mathbf{5 5 0 0 . 8}$ & 275.04 \\
\hline 2017 & 1221 & $20 \%$ & $20 \%$ & 488.40 & $\mathbf{5 8 6 0 . 8}$ & 293.04 \\
\hline 2018 & 1242 & $20 \%$ & $20 \%$ & 496.80 & $\mathbf{5 9 6 1 . 6}$ & 298.08 \\
\hline
\end{tabular}

Models of both scenarios (minimum and average) show that emigration is still beneficial for the Estonian economy. The value of unpaid taxes, even in the most positive case scenario, was reaching 5961 EUR per person annually (Table 4). Although this amount exceeds any other Baltic emigrant possible positive impact on the economy, it is nevertheless still two times less than the already existing annual remittances flow.

Both minimum \& average impact scenarios indicated that regionally, emigrants could heavily support Estonian Narva, Latvian Daugavpils and Lithuanian Visaginas if they stayed and paid at least VAT from a minimum salary. The minimum envisaged impact on regional economies from unpaid taxes in the minimum impact scenario is 
measured from 2 million EUR up to 7.8 million EUR annually (Table 5). The impact is very much dependent on the number of emmigrants and level of wages.

Table 5. Model of emigration's minimum-impact scenario on the Baltic regions (author's calculations based on National Statistics Bureau data)

\begin{tabular}{|l|c|c|c|}
\hline & $\begin{array}{c}\text { Minimum annual unpaid taxes } \\
\text { per 1 emigrant (EUR) }\end{array}$ & $\begin{array}{c}\text { Number of } \\
\text { emmigrants }\end{array}$ & $\begin{array}{c}\text { Total amount of unpaid } \\
\text { taxes (mln.EUR) }\end{array}$ \\
\hline Daugavpils & 937.4 & 8720 & 8.2 \\
\hline Visaginas & 866.7 & 2338 & 2.0 \\
\hline Narva & 1081.1 & 7170 & 7.8 \\
\hline
\end{tabular}

In the average impact scenario envisaged the annual effect from unpaid taxes is 7.7 million EUR in Visaginas, 39.1 million EUR in Narva and 39.5 million EUR in Daugavpils (Table 6). This means that the regional cities could have earned up to 39 million EUR if emigrants came back and started to pay VAT and income tax from an average salary. The overall economic impact depends on average salary level and the size of the emigration in the corresponding country.

Table 6. Model of emigration's average-impact scenario on the Baltic regions (author's calculations based on National Statistics Bureau data)

\begin{tabular}{|l|c|c|c|}
\hline & $\begin{array}{c}\text { Average annual unpaid taxes per } \\
\text { 1 emigrant (EUR) }\end{array}$ & $\begin{array}{c}\text { Number of } \\
\text { emmigrants }\end{array}$ & $\begin{array}{c}\text { Total amount of unpaid } \\
\text { taxes (mln.EUR) }\end{array}$ \\
\hline Daugavpils & 4533.8 & 8720 & 39.5 \\
\hline Visaginas & 3310.2 & 2338 & 7.7 \\
\hline Narva & 5451.8 & 7170 & 39.1 \\
\hline
\end{tabular}

The calculated effect from unpaid taxes, even in an average impact scenario, reaches only $70 \%$ of the annual total amount of remittances. That means that with the current socio-economic environment in the regions of the Baltic countries it will be at least $30 \%$ more beneficial for local economies to receive remittances from abroad. Of course, this assumption is based only on those economic factors, which are included in the average impact model.

\section{Conclusion}

Economically lagging behind regions in the Baltics are suffering from similar problems: low economic activity, high emigration and very limited opportunities in the regions. Even though it is evident that remittances are an essential part of the economy, the amount of remittances has been decreasing over the past five years.

Nevertheless, the economic weight of each emigrant, in terms of capability of paying taxes, is growing. In the light of the economic growth of the Baltic economies minimum and average salaries are increasing, which as well boosts the total value of taxes, which emigrants could have paid.

All three Baltic countries are currently benefiting from remittances, on average receiving 3.5 billion EUR annually. With the current socio-economic environment, the 
benefit from remittances is bigger than the total amount of unpaid taxes of all the emigrants living abroad.

Among the three Baltic countries, the most generous regional emigrants are from Narva, generating more than 9000 EUR annually per person in the form of remittances. Emigrants from Daugavpils are sending, on average, annually sending 6700 EUR per person and emigrants from Visaginas 4600 EUR per person.

The model for the emigration average-impact scenario in the Baltic regions showed that the amount of taxes, which emigrants could have paid, is not exceeding the $75 \%$ threshold. Daugavpils - 68\%, Visaginas - 72\% and Narva - $60 \%$ of remittances.

Interestingly, in Estonia, where the average wage is higher than in the other two countries, taxes are not surpassing the $60 \%$ threshold of remittances. The reason for Estonian Narva being different and for the other two Baltic economically lagging regions being similar could be rather geographical. Daugavpils and Visaginas are located in close proximity to each other and the communities are very much interconnected.

It is important to mention, that both models are taking into account a very limited number of factors, which makes it possible to measure only the short-term impact of emigration. In a long-term calculation many additional factors must be considered, such as emigrant intellectual capacity, possible value-adding production, investments in social care, education and others.

\section{Acknowledgement}

This study was supported by National Research Program Project N ${ }^{0}$.VPP-IZM2018/1-0015.

\section{Kopsavilkums}

Šajā rakstā autors pēta emigrācijas ekonomisko nozīmi trīs Baltijas valstīs un salīizina tās ietekmi uz trim atpalikušiem Baltijas reǵioniem - Visaginu (Lietuva), Daugavpili (Latvija) un Narvu (Igaunija). Analizēta pēdējo desmit gadu informācija. Tiek pētita emigrācijas ietekme uz ekonomiku, ņemot vērā emigrācijas plūsmas apjomu, nodokḷ sistēmas atšḳirības un naudas pārvedumu apjomu Baltijas valstīs.

Šî pētījuma mērḳis ir 1) izmērìt emigrācijas ekonomiskās sekas uz Baltijas valstīm; 2) salīinināt emigrācijas procesu un tā atšḳirības Baltijas valstīs un 3) izmērīt kopējo emigrācijas ietekmi uz ekonomiski atpalikušiem reǵioniem.

Emigrācijas ietekme uz Baltijas valstu ekonomiku vērtēta, summējot tās negatīvos un pozitīvos faktorus. Darbā izmantotas divas kvantitatīvas pieejas, lai novērtētu emigrācijas ietekmi uz izvēlētajām Baltijas valstīm un izraudzìto reǵionu ekonomiku. Katrā no šiem scenārijiem ir dažādi parametru kopumi, un š̄s kombinācijas apraksta migrācijas ekonomisko ietekmi. Pieeju pamatā esošās formulas ar nelielām pārmaiņām var tikt izmantotas līdzīgu jautājumu izskatǐšanai citos reǵionos un valstīs.

\section{References}

Borjas, G. J. (1995). The economic benefits from immigration. Journal of Economic Perspectives, 9 (2/3), 3-22.

Hazans, M. (2013). Emigration from Latvia: Recent trends and economic impact. Coping with emigration in Baltic and East European countries. OECD Publishing, 65-110. 
King, R., Skeldon R. and Vullnetari, J. (2008). Internal and International Migration: Bridging the Theoretical Divide. Sussex: Centre for Migration Research, University of Sussex.

Kozlovs, M. (2014). Comparative analysis of economic migration in Serbia and Latvia in period 2008 till 2013. University of Latvia, 1-69.

Krasnopjorov, O. (2011). Cik cilvēku pameta Latviju un cik vēl pametīs? (How many people emigrated from Latvia and how many are planning to do so?). http://www.makroekonomika.lv/cikcilveku-latviju-pameta-un-cik-vel-pametis (19.12.2018).

Migration Policy Centre (2013). The politics of European Union migration governance. http://cadmus.eui.eu/handle/1814/57305?show=full (21.1.2019)

Ratha, D., Mohapatra, S., Scheja, E. (2011). Impact of migration on economic and social development: A review of evidence and emerging Issues. World Bank Policy Research Working Paper No 5558 .

European Commission (2017). Competitiveness in low-income and low-growth regions. https://ec.europa.eu/regional_policy/sources/docgener/studies/pdf/lagging_regions\%20report_en.pdf (14.1.2019)

World Bank (2017). Migration and Remittances Recent developments and outlook. https://www.worldbank.org/en/topic/labormarkets/brief/migration-and-remittances (21.1.2019)

\title{
EXPLORING LABOUR MIGRATION FROM LATVIA: GEOGRAPHIES OF ORIGIN
}

\section{Darba spēka migrācijas izpēte Latvijā: izbraukšanas ǵeogrāfija}

\author{
Elīna Apsīte-Beriṇa, Ģirts Burgmanis, Zaiga Krišjāne \\ University of Latvia, Faculty of Geography and Earth Sciences
}

Elina.apsite-berina@lu.Iv

\begin{abstract}
The aim of this study is to explore labour migration geographies in order to reveal peculiar aspects of emigration spatial distributions between core and peripheral sending regions and destination country choices. In this study the term core is considered the capital of Latvia, Rìga, and the term periphery is considered as the remaining statistical regions in Latvia as well as the receiving countries which are identified as the UK, Ireland, Germany, Norway and Sweden. The study is based on a database derived from an online survey and analysed through statistical methods.

The findings suggest that the profiles of labour migrants differ sharply in terms of geographic context in Latvia. Migrants from the core part of the country were more educated, skilled and had worked in the tertiary sector of the economy prior moving away from Latvia than their counterparts from peripheral regions. In addition, other findings show that migrants from the core are less likely to be circular migrants, but more often than not, migrants from the periphery use their own efforts to find a job in the destination country. In terms of destination country geographies, emigrants from the core more often choose Germany, Norway and Sweden, but emigrants with lower hierarchy in education and occupation levels engage more in circular movements by repeatedly going to Ireland and the UK.
\end{abstract}

This paper was supported by the project 1.1.1.2/VIAA/1/16/184.

Keywords: labour migration, core, periphery, Latvia, youth

\section{Introduction}

Sources of human capital as substantial forces in the economic development of Western countries are often attracted from poorer economies. Migration flows from 